\title{
New reporting of a residual population of Italian crested newt Triturus carnifex (Laurenti, 1768) (Amphibia Caudata) within the city of Rome (Italy)
}

\author{
Antonino Sciortino'* \& Mauro Grano² \\ ${ }^{1}$ Via Valsolda 149, 00141 Rome, Italy; e-mail: astolinto@hotmail.com \\ ${ }^{2}$ Societas Herpetologica Italica, Sezione Lazio, Rome, Italy; e-mail: elaphe58@yahoo.it \\ *Corresponding author
}

\begin{abstract}
In this paper, the news is given of a residual population of Italian crested newt Triturus carnifex (Laurenti, 1768) Amphibia Caudata) in a residential area within the city of Rome. The serious environmental threats for this small population are highlighted.
\end{abstract}

KEY WORDS Italian crested newt; Triturus carnifex; urban biodiversity; Rome; Central Italy.

Received 19.02.2021; accepted 28.04.2021; published online 30.06.2021

\section{INTRODUCTION}

Triturus carnifex, the Italian crested newt, is a large newt, with females measuring up to $180 \mathrm{~mm}$ and males up to $150 \mathrm{~mm}$ in total length (Arnold, 2002). Triturus carnifex is native of Italy, southcentral Europe, and the western Balkans (Edgar \& Bird, 2006). It is also found in France/Switzerland, in the Lake Geneva region, though it is thought that this population has been introduced (Edgar \& Bird, 2006). A population of T. carnifex has also been established in the U.K., at Surrey, for some years, most likely escaped from the pet trade (Lever, 1980; Brede et al., 2000). This species makes use of a wide variety of habitats, including dry Mediterranean regions and beech woodlands, at altitudes up to 2140 meters (Arnold, 2002; Edgar \& Bird, 2006).

Triturus carnifex strongly prefers still waters for breeding, either temporary or permanent, but will use pools within streams, or rivers with slow flow if necessary (Edgar \& Bird, 2006). Artificial water bodies may also be used, such as garden ponds and water-filled gravel pits. In parts of northern Italy, Triturus carnifex has also been found within rice paddies (Andreone \& Marconi, 2006). Crested newts are primarily nocturnal and partially aquatic (Edgar \& Bird, 2006). Triturus carnifex spends an average of four months a year in water, during the spring (Edgar \& Bird, 2006). Breeding occurs during this time, and females each lay about 250 eggs (Edgar \& Bird, 2006). Due to a lethal mutation on the first chromosome, the whole species complex experiences $50 \%$ mortality during egg development (Wallace, 1994; D’Amen et al., 2006). During the terrestrial phase, the adult diet consists of terrestrial invertebrates (insects, earthworms, woodlice, mollusks) (Edgar \& Bird, 2006). During the aquatic phase, adult crested newts feed on aquatic invertebrates, juvenile newts, and tadpoles, and have also been reported to consume shed amphibian skin. Crested newt larvae will eat frog tadpoles and other larval salamanders, in addition to a wide range of aquatic invertebrates (Edgar \& Bird, 2006). 


\section{MATERIAL AND METHODS}

\section{Study area}

Within the territory of the Municipality of Rome, there are numerous waterways, some of which pour directly into the Tyrrhenian Sea, others into the Tiber River and others into the Aniene River. The ditch of Casale dei Pazzi belongs to this last category, being one of the right tributaries of the Aniene River. The ditch begins in the district of Fondi di Tor Lupara, at m. 110 a.s.1., with the name of Fosso della Cesarina. From its beginning the ditch descends to the valley towards the southwest, receiving on the left the contribution of the ditch of the Case Nuove and on the right that of the ditch of the Cinquina. Downstream of this confluence it takes the name of the ditch of Casale dei Pazzi and continues downstream to the confluence with the Aniene, receiving on the left the contribution of the ditch of San Basilio. The shaft length of the ditch is $9.8 \mathrm{~km}$ and its average slope is $0.9 \%$.

The study area is located in one of the green areas of Talenti (Fig. 1), which is a district of the III Municipality of Rome. The neighborhood covers an area of about 150 hectares, with a population of over 30,000 inhabitants, and is limited by the streets: Via della Bufalotta, Via di Casal Boccone, Via Nomentana, Via Ettore Romagnoli, and Viale Jonio. The portion of the ditch that has not been filled in, where the population of $T$. carnifex is present, is located in the Talenti Park, a green area that has been the subject of redevelopment works since 2001 and was opened to the public in 2018. A short distance away there are a cycle path, a parking lot and two very busy roads (Via Ugo Ojetti and Via di Casal Boccone). The geographic coordinates are $41^{\circ} 57^{\prime} 06,56^{\prime \prime} \mathrm{N} ; 12^{\circ} 33^{\prime} 37,51^{\prime \prime} \mathrm{E} ; 24 \mathrm{~m}$ a.s.1.

\section{Methods}

The observations of the place took place between September 2018 and February 2019 at least once a month. The pool where the newts were found (Fig. 2) is a rectangular artificial basin, approximately 30 meters long and 6 meters wide. It is a permanent basin, about 50 centimeters deep and, during summers, in the period of observations, the water level highly decreases but never drains.
It is developed in a northeast and south-west direction. Most of it is located below the overpass, where the street, Via di Casal Boccone, passes on the canal. This part is surrounded by cement walls and it is always in the shade. In south-west direction there is a sunny zone, mainly in morning and early afternoon hours, depending on the season. This part is rich in plants; there is a group of reeds with Typha sp. and Carex sp. The substratum of this part of the pond is covered with silt and a little stream of water emissary continues in the canal, full of vegetation. On the water surface lies Lemna minor covering the whole lightened part in some periods of the year.

In the observation period, near the lake, were observed a red fox, Vulpes vulpes (Linnaeus, 1758), brown rats, Rattus norvegicus (Berkenhout 1769), common moorhens (Gallinula chloropus, Linnaeus, 1758) and many birds that drink inside it. Many Pulmonates (Gastropoda Pulmonata) are present: Milax nigricans (Philippi, 1836) was very abundant, Tandonia sowerbyi (A. Férussac, 1823), Eobania vermiculata (O.F. Müller, 1774), Testacella scutulum G.B. Sowerby I, 1821 and Cornu aspersum (O.F. Müller, 1774). The area is rich of Lumbricidae too. Pulmonata and Lumbricidae can be prey of Amphibians. Inside the lake we report the presence of alien species too: three specimens of Trachemys scripta (Thunberg in Schoepff, 1792) and a big goldfish, Carassius auratus (Linnaeus, 1758) were noted. Moreover, mainly in summer, there is the presence of a large community of Green frog, Pelophylax sp. The pond is rich of insect: mainly backswimmers (Notonectidae Latreille, 1802), Ephemeroptera larvae (Hyatt \& Arms, 1891) and Odonata larvae (Fabricius, 1793). It is rich in Crustacea too: mainly Cladocera (Latreille, 1829) and Copepoda (Milne Edwards, 1840). The bottom of the reservoir is covered with annelids Tubifex tubifex (Müller, 1774).

In September 2018 a group of adult Italian crested newts Triturus carnifex (Laurenti, 1768) was observed in the pool, in the aquatic phase. The observations of the newts in the water were confirmed in all the following months of the study, until February 2019. It seems that many individuals survive in the water on winter. With the beginning of the heavy rains that fall on Rome in the period from 27th October since 6th November were 
observed, on a little street parallel to the stream, three terrestrial items of not large size: $8.7 \mathrm{~cm}, 10.8$ $\mathrm{cm}$ and $7.2 \mathrm{~cm}$ (Fig. 3) and an item dead crushed in the adjacent auto-parking (Fig. 4). Other terrestrial items was observed only in the period from 20th November since 25th November when there were severe thunderstorms (size of $6.7 \mathrm{~cm}$, $11.9 \mathrm{~cm}$ and $12.4 \mathrm{~cm}$ ). No specimens was observed in terrestrial phase in December, January and February when temperatures were almost always below 10 degrees. During the inspections were seen some specimens of Balearic green toad, Bufotes balearicus (Boettger, 1880), not reported for the site.

The first observation of a female of Italian crested newt (Triturus carnifex) in the pond was on 27th September 2018. On 13rd October 2018 some items was photographed. Subsequently newts and toads in the pond under the bridge and on a 500 meters long street parallel to the stream, were numbered. The observations were made

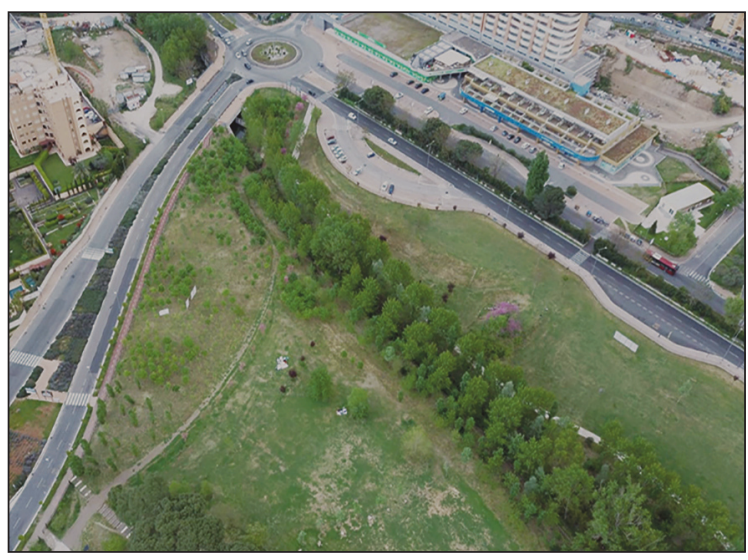

Figure 1. Green area near Talenti, Rome (Italy).

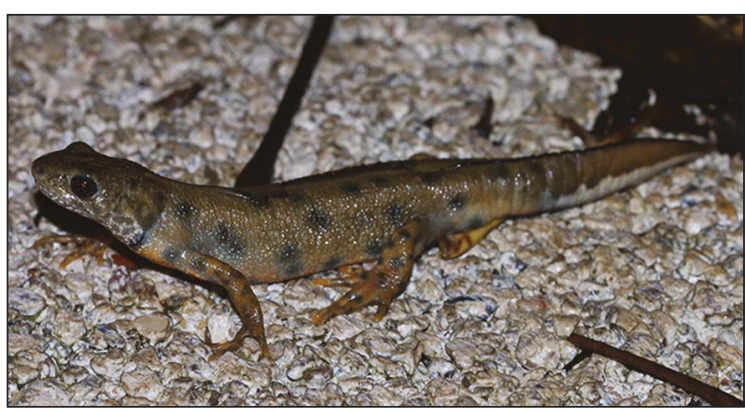

Figure 3. Triturus carnifex from Talenti, Rome (Italy). after sunset from $7.00 \mathrm{pm}$ to $10.00 \mathrm{pm}$. Air temperature and the weather conditions were recorded.

\section{RESULTS AND CONCLUSIONS}

The crested newt's species are among the most rapidly declining amphibian taxa in Europe and are protected by law (Edgar \& Bird, 2006). In Lazio these newts are widespread throughout the regional territory (Bologna et al., 2000). In the province of Rome Triturus carnifex is found along the main rivers (Tiber, Aniene and Mignone), in the entire mountain ranges (Tolfa, Sabatini, Cornicolani, Lucretili, Tiburtini, Ruffi, Prenestini, Affiliani, Lepini, Simbruini and Alban Hills), along the coastal strip and in suburban area environments (Bologna et al., 2007).

Regarding the presence of the species in the city of Rome, within the Grande Raccordo Anulare, the

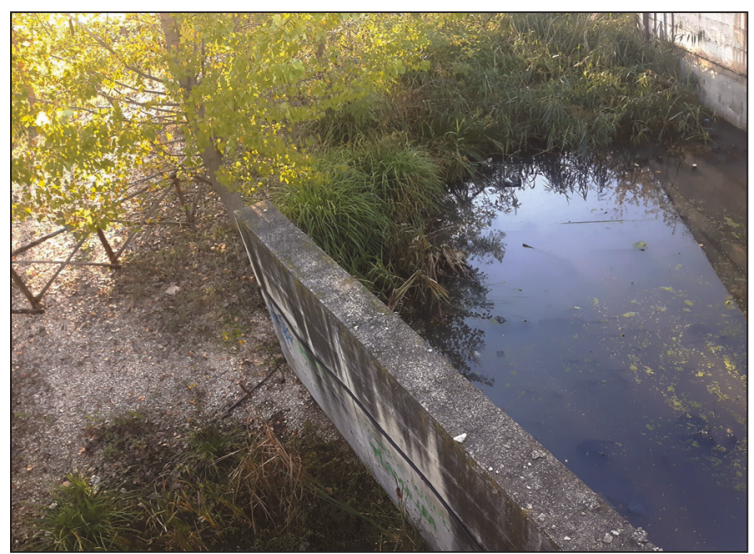

Figure 2. Artificial basin, place of observations.

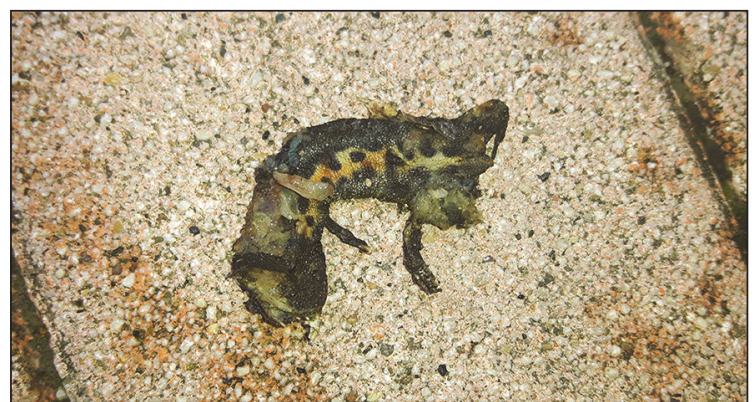

Figure 4. Triturus carnifex dead near the artificial basin. 


\begin{tabular}{|c|c|c|c|c|}
\hline & $\begin{array}{c}\text { Newts } \\
\text { (T. carnifex) in } \\
\text { the water }\end{array}$ & $\begin{array}{c}\text { Newts } \\
\begin{array}{c}\text { (T. } \text { carnifex) out } \\
\text { of water }\end{array}\end{array}$ & $\begin{array}{c}\text { Balearic green } \\
\text { Toads } \\
(\text { P. balearica })\end{array}$ & Temperature water, rainfall and notes \\
\hline $27 / 02 / 19$ & 6 & 0 & 0 & $5^{\circ} \mathrm{C}$, clear \\
\hline $19 / 02 / 19$ & 9 & 0 & 0 & $7^{\circ} \mathrm{C}$, clear \\
\hline $12 / 02 / 19$ & 0 & 0 & 0 & $1^{\circ} \mathrm{C}$, clear \\
\hline $02 / 02 / 19$ & 7 & 0 & 0 & $9^{\circ} \mathrm{C}$, rain. 3 slugs \\
\hline $20 / 01 / 19$ & 15 & 0 & 0 & $\begin{array}{l}\text { ( } 1 \text { item died). } 7^{\circ} \mathrm{C} \text {, rain. } \\
2 \text { slugs and } 3 \text { earthworm }\end{array}$ \\
\hline $15 / 01 / 19$ & 2 & 0 & 0 & $7^{\circ} \mathrm{C}$, clear \\
\hline 09/01/19 & 0 & 0 & 0 & $4^{\circ} \mathrm{C}$, light rain \\
\hline $05 / 01 / 19$ & 3 & 0 & 0 & $3{ }^{\circ} \mathrm{C}$, light rain \\
\hline $20 / 12 / 18$ & 10 & 0 & 0 & $11^{\circ} \mathrm{C}$, clear \\
\hline $14 / 12 / 18$ & 8 & 0 & 1 & $7^{\circ} \mathrm{C}$, light rain. 3 slugs and 1 earthworm \\
\hline $11 / 12 / 18$ & 0 & 0 & 0 & $\begin{array}{l}2{ }^{\circ} \mathrm{C} \text {, clear. Presence of oily substance on the } \\
\text { surface of the water }\end{array}$ \\
\hline $5 / 12 / 18$ & 0 & 0 & 0 & $10^{\circ} \mathrm{C}$, clear. 20 slugs \\
\hline $30 / 11 / 18$ & 18 & 0 & 0 & $\begin{array}{l}11^{\circ} \mathrm{C} \text {, clear. Grass cut around the canal } 11 \text { slugs } \\
\text { and } 1 \text { earthworm }\end{array}$ \\
\hline $27 / 11 / 18$ & 15 & 0 & 0 & $11^{\circ} \mathrm{C}$, light rain. 3 slugs and 1 earthworm \\
\hline $25 / 11 / 18$ & 17 & $\begin{array}{l}2(12.4 \mathrm{~cm} \text { and } \\
11.9 \mathrm{~cm})\end{array}$ & 1 & $11^{\circ} \mathrm{C}$, rain. 19 slugs and 9 earthworms \\
\hline $24 / 11 / 18$ & 13 & $1(6.7 \mathrm{~cm})$ & 4 & $\begin{array}{l}15^{\circ} \mathrm{C} \text {, thunderstorm. } 20 \text { slugs and } \\
5 \text { earthworms }\end{array}$ \\
\hline $23 / 11 / 18$ & 1 & 0 & 3 & $15^{\circ} \mathrm{C}$, clear and windy \\
\hline $20 / 11 / 18$ & 7 & 1 & 2 & $15^{\circ} \mathrm{C}$, after rain. 9 slugs \\
\hline $14 / 11 / 18$ & 4 & 0 & 0 & $9^{\circ} \mathrm{C}$, clear \\
\hline $11 / 11 / 18$ & 0 & 0 & 0 & $11^{\circ} \mathrm{C}$, after rain. 3 slugs and 3 earthworms \\
\hline $09 / 11 / 18$ & 1 & 0 & 3 & $11^{\circ} \mathrm{C}$, clear \\
\hline $08 / 11 / 18$ & 0 & 0 & 0 & $9^{\circ} \mathrm{C}$, clear \\
\hline $04 / 11 / 18$ & 6 & 0 & 2 & $\begin{array}{l}15^{\circ} \mathrm{C} \text {, after rain. } 11 \text { slugs and } \\
6 \text { earthworms }\end{array}$ \\
\hline $03 / 11 / 18$ & 2 & $1 *$ & 0 & $21^{\circ} \mathrm{C}$, cloudy. 1 slugs \\
\hline $02 / 11 / 18$ & 7 & 1 & $3(8.7 \mathrm{~cm})$ & $18^{\circ} \mathrm{C}$, light rain. 3 slugs and 1 earthworm \\
\hline $28 / 10 / 18$ & 4 & $1(10.8 \mathrm{~cm})$ & 0 & $\begin{array}{l}20^{\circ} \mathrm{C} \text {, after rain. A newt was observed in the car } \\
\text { parking. } 7 \text { slugs and } 1 \text { earthworm }\end{array}$ \\
\hline
\end{tabular}

Table 1. Table of osservations in artificial basin near Talenti (Rome, Italy). The observation of newts in the pond also depends on the turbidity of the water. * Observed died in the parking.

known stations are located in the Tiber Valley in the north, the wide range of the Roman countryside, between Via della Magliana and Via Aurelia, in the southwest, while the area between the EUR district and the Appia Antica seems to represent a historical presence (Bologna et al., 2003). Moreover the species are mentioned for the Acquafredda area (Bruno, 1973), with dubious observations on the 
Cervelletta (Calvario et al., 1998), for the Appia Antica Regional Park (Pratesi, 1975; Angelone et al., 1998) and for the Tenuta dei Massimi (Battisti et al., 1998). In some locations of Lazio, the species was reported before the $80 \mathrm{~s}$, the presence was not reconfirmed because of environmental alterations (Bologna et al., 2000).

They are particularly vulnerable to habitat fragmentation due to their inability to move long distances (Edgar \& Bird, 2006). In addition, $T$. carnifex is highly sensitive to changes in water quality (IUCN, 2006). Thus, another principal threat to this species is loss of aquatic habitat due to pollution. Larval crested newts are also particularly susceptible to predation by fish (Edgar $\&$ Bird, 2006) and consequently the presence of allochthonous fish (Carassius auratus) in the small ditch proves extremely harmful for the survival of the crested newt.

The anthropic impact in this area is high too. Some works to restore the pedestrian underpass to connect the park with new buildings could destroy the site. Moreover, the new "Piano regolatore generale comunale" (PRGC) of Rome provides for the passage of the subway, line $\mathrm{D}$, in the neighborhood with three stops named: Talenti, Pugliese and Ojetti. The line will connect the district with the city center, Salario district and in a southerly direction with Trastevere, San Paolo, Marconi, Magliana and EUR. This enormous work of excavation and substantial modification of the territory will inevitably lead to the complete destruction of the green area and of this residual population.

In recent years, from June to September, the "CineVillage Parco Talenti" initiative has been taking place in the area with the most findings of adults in the terrestrial phase of T. carnifex and of adults of $P$. balearica. This initiative brings many people to visit the park in the evening hours, during which the amphibians start their activity, with the possible increase of the risk of trampling.

\section{REFERENCES}

Andreone F. \& Marconi M., 2006. Triturus carnifex. Atlante degli Anfibi e dei Rettili d'Italia (Atlas of Italian Amphibians and Reptiles). Societas Herpetologica Italica, Edizioni Polistampa, Firenze, 220-225.
Angelone E., Antonelli P., Capretti A.M., Caselli S., Cavagnuolo L., D’Amato L., De Carolis M.C., De Santis M., Dominici A., Giucca F., Lauri C., Parisi P. \& Piroli R., 1998. Studio e Tutela della Fauna del Parco Regionale dell'Appia Antica. In: Bologna M.A., Carpaneto G.M., Cignini B. (eds), Atti del I Convegno Nazionale Fauna Urbana (Roma, 12 Aprile 1997). Fratelli Palombi Editori, pp. 287-290.

Arnold N., 2002. Reptiles and Amphibians of Europe. Princeton University Press, Princeton.

Battisti C., Calvario E., Pacini A., Teofili C., Venchi A. \& Zocchi A., 1998. L'Infernaccio e la Tenuta dei Massimi: un'area ad elevata biodiversità ambientale all'interno del Grande Raccordo Anulare di Roma. In: Bologna M.A., Carpaneto G.M., Cignini B. (Eds.), Atti del I Conv. Naz. Fauna Urbana (Roma, 12 Aprile 1997). Fratelli Palombi Editori, pp. 277279.

Bologna M.A., Capula M. \& Carpaneto G.M., 2000. Anfibi e Rettili del Lazio. Fratelli Palombi Editori, Roma, 160 pp.

Bologna M.A., Capula M., Carpaneto G.M., Cignini B., Marangoni C., Venchi A. \& Zapparoli M., 2003. Anfibi e Rettili a Roma. Atlante e guida delle specie presenti in città. Comune di Roma, Assessorato Ambiente, Assessorato Cultura, Stilgrafica srl, Roma, $112 \mathrm{pp}$.

Bologna M.A., Salvi D. \& Pitzalis M., 2007. Atlante degli Anfibi e dei Rettili della Provincia di Roma. Provincia di Roma, Gangemi Editore, Roma, 192 pp.

Brede E.G., Thorpe R.S., Arntzen J.W. \& Langton T.E.S., 2000. A morphometric study of a hybrid newt population (Triturus cristatus/T. carnifex): Beam Brook Nurseries, Surrey, U.K. Biological Journal of the Linnaean Society, 70: 685-695. https://doi.org/10.1006/bij1.1999.0423.

Bruno S., 1973. Anfibi d'Italia: Caudata. Natura, 64: 209-450.

Calvario E., Del Moro M.A., Marangoni C., Pietromarchi A., Sarrocco S., Venchi A. \& Bologna M.A., 1998. I Vertebrati della Cervelletta, un'area umida relittuale ad elevata ricchezza di specie all'interno della città di Roma: proposte di gestione. In: Bologna M.A., Carpaneto G.M., Cignini B. (Eds), Atti del I Conv. Naz. Fauna Urbana (Roma, 12 Aprile 1997). Fratelli Palombi Editori, pp. 283-286.

D’Amen M., Vignoli L. \& Bologna M., 2006. The normal development and the chromosome No. 1 syndrome in Triturus carnifex carnifex (Caudata, Salamandridae). Italian Journal of Zoology, 73: 325333.

https://doi.org/10.1080/11250000600973410

Edgar P. \& Bird D.R., 2006. Action Plan for the Conservation of the Crested Newt Triturus cristatus species complex in Europe. Convention on 
the Conservation of European Wildlife and Natural Habitats. Strasbourg, 2006 Nov 26-30.

IUCN, Conservation International, and Nature Serve. 2006. Global Amphibian Assessment. www.globalamphibians.org. Accessed on 2 April 2007.
Lever C., 1980. Observations at Beam Brook Nurseries. British Herpetological Society Bulletin, 1: 21-23.

Pratesi F., 1975. Clandestini in città. Piante e animali dell'ambiente urbano. A. Mondadori, Verona, $180 \mathrm{pp}$.

Wallace H., 1994. The balanced lethal system of crested newts. Heredity, 73: 41-46. 